\title{
The Effect of Individual and Environmental Motivations on YouTuber Followers' Behavioral Changes*
}

\author{
F. Görgün Deveci1 $\odot$, Sevtap Ünal2 $₫$
}

\begin{abstract}
This study aimed to determine the effective factors on the behavioral changes of YouTuber followers. Accordingly, it was targeted to determine the effect of the individual, environmental motivations, and YouTuber characteristics on the change of followers' behavior through the online flow process. Meanwhile, the mediating role of opinion seeking and the moderator role of the fear of missing out have been discussed. The main mass consisted of 520 female consumers who live in Istanbul, are at least 18 years of age, and follow at least one YouTuber in the makeup/cosmetic/beauty segment. Structural equation modelling was used to analyze the data. Findings showed that three subdimensions of knowledge-sharing motivations, which are consumer interactivity, trust, and consumer expertise; four subdimensions of fundamental interpersonal relation orientations, which are the need to be part of a group, avoidance of similarity and unpopular choice counter-conformity, creative choice counter-conformity, and the need for personal growth; and social presence have a positive, community identification and that YouTuber characteristics have a negative effect on online flow. However, social norms have no effect. Meanwhile, online flow is effective on the behavioral changes of followers. Finally, opinion seeking has a mediating role whereas the fear of missing out has a moderating role.
\end{abstract}

Keywords

Individual Motivations, Environmental Motivations, YouTuber Characteristics, Online Flow Theory, Behavioral Changes

\section{Introduction}

Nowadays, knowledge-sharing and communication between individuals have been carried out mostly through social media tools, and video content consumption has also increased (Khan, 2017). At this point, understanding individual motivations is important. Therefore, an attempt to reveal individual motivations' effects on online flow has been made. YouTube attracts individuals by emphasizing a sense of community and promoting web-based social relationships (Yang, Hsu, \& Tan, 2010). Therefore, the social interactivity needs of the users

\footnotetext{
* "This research is derived from the first author's doctoral dissertation. This research derived from "The Effect of Individual and Environmental Motivations on YouTuber Followers' Behavioral Changes (Bireysel ve Çevresel Motivasyonların YouTuber Takipçilerinin Davranışsal Değişimleri Üzerine Etkisi)" doctoral dissertation, which was completed on 29.04.2019 by F. Görgün DEVECI and under the supervision of Professor Sevtap ÜNAL in Atatürk University, Erzurum/Turkey, Institute of Social Science, Department of Business Administration, Product Management and Marketing Field."

1 Corresponding Author: F. Görgün Deveci (Res. Asst. Dr.), Atatürk University, Faculty of Economics and Administrative Sciences, Department of Business Administration, Production Management and Marketing, Erzurum, Turkey. E-mail: gorgun.deveci@atauni.edu.tr ORCID: 0000-0001-8987-2478

2 Sevtap Ünal (Prof. Dr.), İzmir Katip Çelebi University, Faculty of Economics and Administrative Sciences, Department of International Trade and Business Administration, İzmir, Turkey. E-mail: sevtap.unal@ikcu.edu.tr ORCID: 0000-0002-3227-0756

To cite this article: Deveci, F. G., \& Unal, S. (2021). The Effect of Individual and Environmental Motivations on YouTuber Followers' Behavioral Changes. Istanbul Business Research, 50(2), 435-463. http://doi.org/10.26650/ibr.2021.50.844527
} 
are another factor to be taken into consideration. Therefore, an attempt to examine the environmental motivations' effects on online flow has been done. YouTubers are becoming increasingly famous and have become individuals who are searched for, praised, and imitated by millions of followers (García-Rapp, 2016). It is important to determine the characteristics of following YouTubers and to know which of their characteristics drives people to follow them. For this reason, an attempt has been made to determine YouTuber characteristics' effects on online flow. Online flow theory is important to understand online consumer behavior (Hsu, Chang, \& Chen, 2012). Since the conceptual model has a consumer-oriented perspective, change of behaviors has been attempted to be examined through the online flow theory. Because of the changing roles of individuals in online environments, the question of whether opinion-seeking has a mediating effect on the relationship between online flow and followers' behavioral changes was examined. The fear of missing out (FoMO) is a basic source of motivation that arises from an individual's desire for interpersonal attachment and is shaped by the need of being a part of a group (Franchina, Abeele, van Rooij, Lo Coco, \& De Marez, 2018). It was thought that individuals with FoMO would become more quickly involved in the online flow process and assumed that the relationship between individual motivations and online flow towards behavioral change would strengthen. Therefore, revealing the moderating role of the FoMO in the relationship between these two variables has been sought. The variables used in the conceptual model were brought together to explain the actions of YouTuber followers and were considered important variables in terms of explaining consumer behaviors. There are many studies on different social media tools in the relevant literature. YouTube has been a relatively neglected tool among the other social media sites. Due to the limited number of studies on this platform, the current study is based on the YouTube platform. In accordance with this, consumer-oriented model proposal, individual motivations, environmental motivations, and YouTuber characteristics can be understood and will enable new and different studies in this field. The findings will provide some insights for researchers. Meanwhile, this study will contribute to the individuals who want to be YouTubers, establish partnerships, and create their own collaborations.

\section{Theoretical Background}

\section{Individual Motivations}

\section{Knowledge sharing motivations}

Knowledge-sharing is defined as "the communication process between two or more participants involving the provision and acquisition of information" (Cited by, Jadin, Gnambs, \& Batinic, 2013:2011). Several studies have emphasized the importance of knowledge-sharing motivations in online communities (Lai \& Chen, 2014) and asserted that online communities 
facilitate knowledge-sharing (Zhang, Liu, Deng, \& Chen, 2017). In this study, five knowledge-sharing motivations were addressed.

Consumer interactivity is "the degree to which users of a medium can influence the form or content of the mediated environment" (Steuer, 1992:84). Researchers have found that perceived interactivity affects online consumer behavior, memory, choices, attitudes toward a website, and evaluations of the website's effectiveness ( $\mathrm{Wu}, \mathrm{Hu}, \& \mathrm{Wu}, 2010$ ).

Reciprocity is a fair and mutual knowledge-exchange behavior (Liu, Cheung, \& Lee, 2016:692). This dimension facilitates information-sharing in social networking sites (Tang, Zhao, \& Liu, 2016) and the effective quality of sharing (Chang \& Chuang, 2011).

Reputation is how an individual is perceived by others (Choi, 2015). Reputation in online communities will increase expertise, and individuals will be able to demonstrate their expertise to others (Yan, Wang, Chen, \& Zhang, 2016).

Trust is the belief that someone or somethings is honest, trustworthy, good, and influential (Safa \& İsmail, 2013). As trust level increases, knowledge-sharing also increases (Chang $\&$ Chuang, 2011), and trust has a positive effect on word-of-mouth communication (Choi, 2015).

Consumer expertise is "the ability to perform product-related tasks successfully" (Alba \& Hutchinson, 1987:411). Generally, consumers with high expertise are less sensitive to interpersonal effects and rely on their own experience in purchasing decisions (Cheung, Xiao \& Liu, 2012). They also share their knowledge more than low expertise consumers (Ku, Wei, \& Hsiao, 2012). Accordingly, the following hypotheses have been developed:

- H1. Knowledge-sharing motivations are effective on online flow.

- H1a. Consumer interactivity is effective on online flow.

- H1b. Reciprocity is effective on online flow.

- H1c. Reputation is effective on online flow.

- H1d. Trust is effective on online flow.

- H1e. Consumer expertise is effective on online flow.

\section{Fundamental Interpersonal Relations Orientation Theory (FIRO)}

Fundamental interpersonal relations orientation theory is one of the interpersonal behavior theories and is abbreviated as FIRO (Jenster, 2010). According to the theory, three basic interpersonal needs are satisfied through interaction with others: inclusion, affection, and 
control, and there are four fundamental needs in terms of online content. These are the need to be a part of a group, the need for individualization (uniqueness), the need to be altruistic, and the need for personal growth (Ho \& Dempsey, 2010).

According to Schutz (1966), inclusion is the idea that individuals can establish interpersonal interaction and togetherness; it is also the need to be different from others (Cited by, Hochanadel, 2014:23). The need to be a part of a group, which is the first subdimension of inclusion, is when an individual experiences a system/environment and then feels themself as an inseparable part of it (Zhao, Lu, Wang, Chau \& Zhang, 2012: 576). The need for individualization, which is the second subdimension of inclusion, is the desire that the individual has a unique product which will make it different from other individuals (Ruvio, Shoham, \& Brenčič, 2008). The need for individualization consists of three main dimensions. These are creative choice counter-conformity, unpopular choice counter-conformity, and avoidance of similarity (Bhaduri \& Stanforth, 2016).

Affection is the ability to communicate with others more easily at the point of interaction and communication. This dimension is linked with the concept of altruism (Ho \& Dempsey, 2010). Altruism refers to "the degree to which a person was willing to increase other people's welfare without expecting returns" (Hsu \& Lin, 2008:68).

Control is the desire to affect other individuals in direction of the need for personal growth (Huang, Chen \& Wang, 2012; Ho \& Dempsey, 2010). Personal growth, which is a subdimension of control, is the determinant of an individual's need to control their life (Robitschek, 1998:184). The desire of personal growth enables knowledge-sharing and expertise (Hochanadel, 2014).

Hochanadel's (2014) research results have shown that the "need to belong" is the predictor variable in terms of both opinion-seeking, passing, and giving. Besides this "inclusion" dimension was the main motivation for e-word-of-mouth communication behaviors. Ho \& Dempsey (2010) determined that individualistic and altruistic internet users tend to use and receive online content more. Accordingly, the following hypotheses have been developed:

- H2. FIRO is effective on online flow.

- H2a. The need to be part of a group is effective on online flow.

- H2b. The need to be different is effective on online flow.

- H2c. The need to be altruistic is effective on online flow.

- H2d. The need for personal growth is effective on online flow. 


\section{Environmental Motivations}

\section{Community identification}

Identity is the answer to the question of "Who am I?" (Ma \& Agarwal, 2007:45). In online communities, users often share their statuses, interests, and behaviors with other users. This data reflects users' personalities, experiences, statuses, and social attitudes. Meanwhile, it helps individuals understand the social and personal identification of other individuals (Jin, Li, Zhong, \& Zhai, 2015). Shen, Lee, Cheung, \& Chen (2010) found a positive relationship between knowledge-sharing and social identity in online communities. Accordingly, H3 hypothesis has been developed.

- H3. Community identification is effective on online flow.

\section{Social norms}

According to Wang \& Chen (2012:571), social norms are "the common beliefs and acceptable behavioral standards of the social group". Consumers adjust their behavior in accordance with social norms and aim to make a good impression on other individuals (Wang, Oppewal, \& Thomas, 2017). Zhou (2011) found that social identity and group norms have an effect on online community user participation. Yang et al. (2010) stated that the intention to use YouTube for video-sharing is affected by social norms. Accordingly, H4 hypothesis has been developed.

- H4. Social norms are effective on online flow.

\section{Social presence}

Social presence is the degree to which an individual is perceived as "real" in a mediated communication environment (Thomas, West, \& Borup, 2017). While social presence is unidimensionally examined, it is also studied multi-dimensionally (Kim, Song, \& Luo, 2016). In their study, Shen \& Khalifa (2008) proposed a three-dimensional structure. Since the awareness dimension is similar to the reputation dimension, affective and cognitive presences were included in the conceptual model.

Affective social presence means the emotional association of users with others in the online community. Online community members who have affective social presence are more willing to share useful knowledge and establish social relationships (Shen et al., 2010).

Cognitive social presence means the perceived reciprocal understanding between communicators. Users who have cognitive social presence are more likely to maintain more effective, efficient, and satisfactory communication (Shen et al., 2010). Accordingly, the following hypotheses have been developed: 
- H5. Social presence is effective on online flow.

- H5a. Affective social presence is effective on online flow.

- H5b. Cognitive social presence is effective on online flow.

\section{YouTuber Characteristics}

Source credibility is one of the most important factors that determine individuals' attitudes and behavioral intentions and ultimately determine their behaviors (Hu, 2015). For this reason, YouTuber characteristics were addressed in the source credibility theory. Trustworthiness, expertise, and attractiveness are defined as the most important characteristics of source (Kim, Lee, \& Prideaux, 2014; Ohanian, 1990). In addition to these characteristics, authenticity, which has appeared in the literature recently, was addressed.

Trustworthiness is the confidence towards a source and the message and accordingly the degree of acceptance of the message (Teng, Khong, Goh, \& Chong, 2014). A YouTuber's trustworthiness depends on the followers' belief that the YouTuber shares their real opinions and experiences related to the products or brands in the video (Zang, 2014).

Expertise is the perception of the source as a valid and correct source of information (Ananda \& Wandebori, 2016; Ohanian, 1990). Beauty-related YouTubers expertness is interpreted as whether they have adequate knowledge about the matter discussed in the video (Zang, 2014).

Attractiveness is to what extent the message is defined by the recipients as appealing (Teng et al., 2014). The attractiveness of a source increases as the "interaction" or replay viewing increases (Lee \& Watkins, 2016). It has been revealed that physically attractive sources are more successful in changing opinions than unattractive sources (Wang, 2014).

Authenticity according to Moulard, Garrity, \& Rice (2015:173) is the behavior of an individual according to their true self. Zietek (2016) found that authenticity is one of the four basic components for influencer marketing. Accordingly, the following hypotheses have been developed:

- H6. YouTuber characteristics are effective on online flow.

- H6a. Expertise is effective on online flow.

- H6b. Trustworthiness is effective on online flow.

- H6c. Attractiveness is effective on online flow.

- H6d. Authenticity is effective on online flow. 


\section{Online Flow Theory}

The most comprehensive definition of online flow is "the state occurring during network navigation which is characterized by a seamless sequence of responses facilitated by machine interactivity, intrinsically enjoyable, accompanied by a loss of self-consciousness, and selfreinforcing" (Hoffman \& Novak,1996:57). In this study, the following flow dimensions were discussed:

Perceived enjoyment, regardless of the performance results arising from system use, is the degree to which using the virtual world is perceived as pleasurable (Pelet, Ettis, \& Cowart, 2017).

Perceived control is the degree to which a person feels powerful in an environment (Wang $\&$ Hsiao, 2012). Therefore, this dimension is generally used in attitude-based models of consumer behavior and acceptance of innovations (Esteban-Millat, Martínez-López, HuertasGarcía, Meseguer, \& Rodríguez-Ardura, 2014).

Concentration is the focus of an individual's attention on an activity (Shim, 2012). Kaur, Dhir, Chen, \& Rajala (2016) have developed a 26-item scale to examine flow experience in social networking services. In the results of their study, six dimensions of flow experience were revealed, one of which was concentration.

Tele-Presence is the perceived experience of presence in an environment through a communication medium (Steuer, 1992). Interactivity affects the level of telepresence (Liu, 2017). It was found that there is positive relationship between interactivity and telepresence. Meanwhile, social presence and telepresence have an impact on instinctive purchases (Shen \& Khalifa, 2012).

Time distortion, in terms of the web, means that time seemingly passes quickly and without the perception of the individual in a computer-mediated environment (Bridges \& Florshe$\mathrm{im}, 2008)$. The use of social media is "immersive and gratifying." Therefore, users forget the elapsed time (Pelet et al., 2017:118). Besides this, time distortion increases opinion leadership behavior (Song, Cho, \& Kim, 2017).

According to Csikszentmihalyi (1990:53), the mergence of action and awareness is the integration of the individual with the activity. Therefore, this activity becomes spontaneous and automatic, and the individuals do not see themselves different from this activity. Similarly, according to Csikszentmihalyi (1988:33), the loss of self-consciousness is a temporary loss of self-awareness (Cited by, Guo, 2004:14).

van Noort, Voorveld, \& van Reijmersdal (2012) determined that the flow is the main determinant which explains the cognitive, attitudinal, and behavioral responses of a brand website. At the same time, interpersonal interaction factors are positively associated with flow experience, and flow experiences affect purchase intention and behavior (Yang, Huang, 
Yang, \& Yang, 2017; Liu, Chu, Huang, \& Chen, 2016; Liu \& Shiue, 2014). Accordingly, H7 hypothesis has been developed:

- H7. Online flow is effective on behavioral changes of followers.

\section{Opinion Seeking}

Opinion seekers imitate the purchase and consumption behaviors of the people they admire, collect information from other consumers in the social communication process, and get advice from more knowledgeable and experienced people than them (Flynn, Goldsmith, \& Eastman, 1996:137). These individuals are followers of opinion leaders and are sensitive to interpersonal effects. While these consumers try to construct their own opinion, they are under the influence of other individuals (Rose \& Kim, 2011). For this reason, opinion seekers see social networking sites as an environment where they can get information and trust these sites (Chu \& Kim, 2011). Kang, Johnson, \& Wu (2014) cited from Senecal and Nantel's (2004) study that the individuals who receive online product recommendations are twice as likely to purchase those products as those who do not. Accordingly, the hypothesis H8 has been developed:

- H8. Opinion seeking has a mediating role in the relationship between online flow and the behavioral changes of followers.

\section{Fear of Missing Out (FoMO)}

FoMO is the desire of being constantly connected with what other individuals are doing (Przybylski, Murayama, DeHaan, \& Gladwell, 2013:1841). FoMO is actually a source of individual motivation and is associated with the need of belonging (Huguenel, 2017). Yin, Liu, $\&$ Lin (2015) found that FoMO is positively associated with continuance intention of using social network sites. Therefore, individuals who have more FoMO are more opinion-seeking (Oberst, Wegmann, Stodt, Brand, \& Chamarro, 2017). Accordingly, the hypotheses have been developed in Table 1. 
Table 1

FoMO Hypotheses

H9. FoMO has a moderating role in the relationship between individual motivations and online flow.

H9a. FoMO has a moderating role in the relationship between knowledge-sharing motivations and online flow.

H9a.a. FoMO has a moderating role in the relationship between consumer interactivity and online flow.

H9a.b. FoMO has a moderating role in the relationship between reciprocity and online flow.

H9a.c. FoMO has a moderating role in the relationship between reputation and online flow.

H9a.d. FoMO has a moderating role in the relationship between trust and online flow.

H9a.e. FoMO has a moderating role in the relationship between consumer expertise and online flow.

H9b. FoMO has a moderating role in the relationship between FIRO and online flow.

H9b.a. FoMO has a moderating role in the relationship between the need to be part of a group and online flow.

H9b.b. FoMO has a moderating role in the relationship between the need to be different and online flow.

H9b.c. FoMO has a moderating role in the relationship between the need to be altruistic and online flow.

H9b.d. FoMO has a moderating role in the relationship between the need for personal growth and online flow.

\section{Behavioral Changes}

The AIDMA model is important in terms of identifying psychological causes in consumer purchasing processes. In the AIDMA model, the consumer goes through the attention, interest, desire, memory, and action steps (Wei \& Lu, 2013). The consumer is passive in the attention, interest, desire, and memory steps but are active in the action step. This model guides the consumer purchase decision process in the internet era (Cao, 2015). In Gomes, Sales, Cavalcante, \& Carvalho's study in 2014, an attempt to understand the purchasing behavior of consumers who consider web videos was made. As a result of the research, a purchasing decision process model which is based on knowledge shared in videos was developed. At the same time, according to Wei \& Lu's (2013) study, celebrity usage in advertising enables the consumer to have more feelings of attention, desire, and action. It also has a significant effect on online customer reviews. In this study, three main dimensions of the theory, which are interest, desire, and action, were discussed. 


\section{Methodology}

\section{Research Model}

The research model is shown in Figure 1.

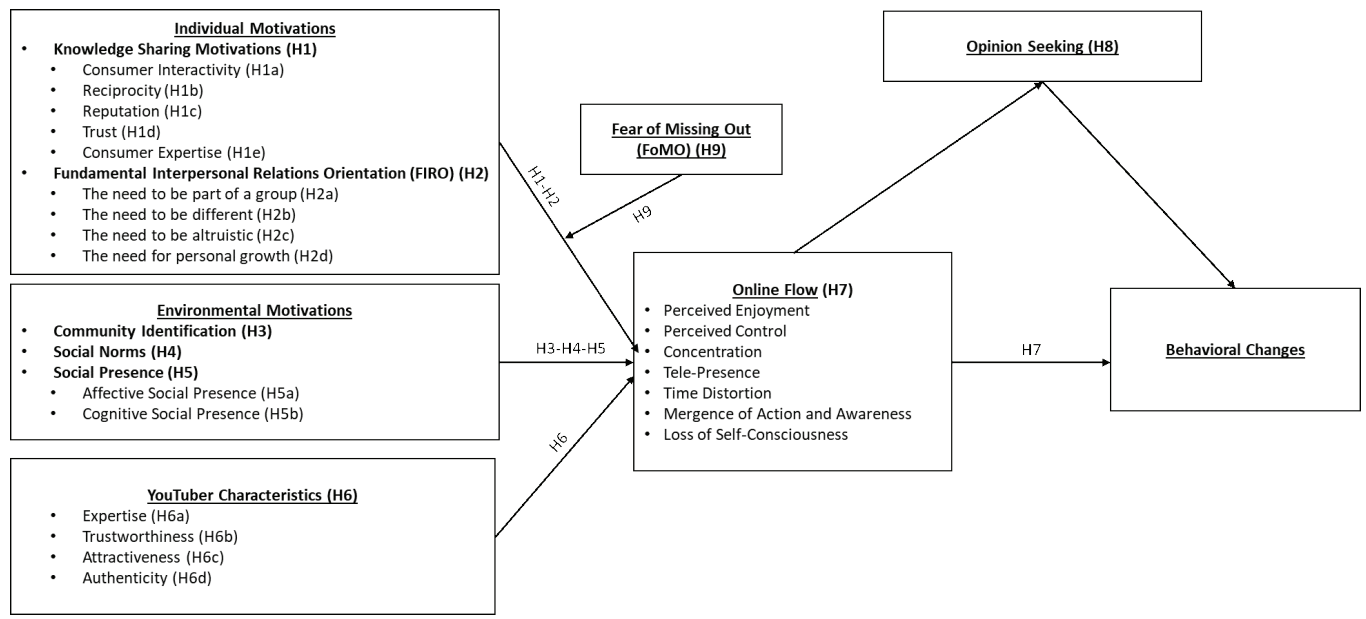

Figure 1. Research Model

\section{Sampling Process}

The main mass consisted of female consumers who live in Istanbul, are at least 18 years of age, and follow at least one YouTuber in makeup/cosmetic/beauty segment. This sample was chosen because Istanbul is a cosmopolitan city and can represent female consumers with different lifestyles. Within the scope of the study, it was not focused on any product group, brand, or YouTuber and/or YouTuber follower, only a specific segment was selected. This segment was makeup/cosmetic/beauty. In order to obtain accurate and reliable information, the respondents were to follow one or more YouTubers in the makeup/cosmetic/beauty segment as a prerequisite. Convenience sampling was used as the sampling method, and a survey procedure was conducted by a research company in Istanbul. The sample size was determined as $n=384$ with $95 \%$ confidence interval and 5\% margin of error (Kurtuluş, 2004: 186). A total of 850 questionnaires were applied. As a result of the elimination of incomplete and incorrect questionnaires, 520 questionnaires were evaluated. 


\section{Measures}

The research scales were adapted from the studies shown in Table 2.

Table 2

Research Scale

\begin{tabular}{|c|c|}
\hline Scales & Adapted From \\
\hline $\begin{array}{l}\text { "Why do you follow makeup/cosmetics/beauty } \\
\text { YouTuber(s)?" }\end{array}$ & Whiting \& Williams (2013) \\
\hline $\begin{array}{l}\text { Knowledge Sharing Motivations } \\
\text { Consumer Interactivity (ET) } \\
\text { Reciprocity (KFB), Reputation (ITI) and Trust (G) } \\
\text { Consumer Expertise (TU) }\end{array}$ & $\begin{array}{l}\text { Wu et al. (2010), Lee, Park, } \\
\text { Kim, Kim, \& Moon (2011) } \\
\text { Hsu \& Lin (2008) } \\
\text { Sohn (2005) }\end{array}$ \\
\hline $\begin{array}{l}\text { FIRO } \\
\text { The need to be part of a group (AIT) } \\
\text { The need to be different (BEN,YAR) } \\
\text { The need to be altruistic } \\
\text { The need for personal growth (KGL) }\end{array}$ & $\begin{array}{l}\text { Leary, Kelly, Cottrell, \& } \\
\text { Schreindorfer (2013) } \\
\text { Ruvio, et al. (2008) } \\
\text { Ma \& Chan (2014) } \\
\text { Robitschek (1998) }\end{array}$ \\
\hline $\begin{array}{l}\text { Environmental Motivations } \\
\text { Community Identification (TK) } \\
\text { Social Norms (SN) } \\
\text { Social Presence (SM) }\end{array}$ & $\begin{array}{c}\text { Hsu \& Lin (2008) } \\
\text { Wang \& Chen (2012) } \\
\text { Shen \& Khalifa (2008) }\end{array}$ \\
\hline $\begin{array}{l}\text { YouTuber Characteristics (YOU) } \\
\text { Expertise (U), Trustworthiness (GV), Attractiveness (C) } \\
\text { and Authenticity (O) }\end{array}$ & $\begin{array}{l}\text { Ohanian (1990), Chapple \& } \\
\text { Cownie (2017) }\end{array}$ \\
\hline $\begin{array}{l}\text { Online Flow (OAT) } \\
\text { Concentration (KON), Perceived Enjoyment (AZ) and } \\
\text { Perceived Control (AKO) }\end{array}$ & Koufaris (2002) \\
\hline $\begin{array}{l}\text { Time Distortion (ZB) } \\
\text { Tele-Presence (TM) } \\
\text { Mergence of Action and Awareness and Loss of Self- } \\
\text { Consciousness }\end{array}$ & $\begin{array}{l}\text { Agarwal \& Karahanna (2000) } \\
\text { Novak, Hoffman \& Yung } \\
\text { (2000), Guo (2004) } \\
\text { Guo (2004). }\end{array}$ \\
\hline Opinion Seeking (FIA) & Flynn et al. (1996) \\
\hline FoMO & Przybylski et al. (2013) \\
\hline $\begin{array}{l}\text { Behavioral Changes (DD) } \\
\text { Interest (IB), Desire (AB) and Action (HG) }\end{array}$ & Wei \& Lu (2013) \\
\hline
\end{tabular}

Individual and environmental motivations, online flow, opinion-seeking, FoMO, and behavioral changes were measured with the 5 -point Likert scale $(5=$ Totally agree, $1=$ Strongly disagree), and YouTuber characteristics were measured by a 7-Point Scale ( $1=$ Close to me, $7=$ Not close to me). The data was analyzed using SPSS and AMOS. In the analysis of the data, descriptive statistics, reliability, exploratory and confirmatory factor analyses, structural equation modeling, and mediating and moderating analyses were employed. 


\section{Results}

\section{Sample Characteristics and Descriptive Statistics}

Participants generally were single (56\%), in 18-25 (35.4\%) and 26-33 (33.6\%) age range, university graduates $(51.2 \%)$, and private-sector employees $(33.8 \%)$. They had a monthly household income of 4301 TL and above.

Many of the participants (55.6\%) stated that they have followed YouTuber(s) for one year or longer and that they watched the video contents "1-3 hours a week." Finally, they generally followed the YouTubers for "entertainment" (49.2\%), "providing convenience and benefits" (41.1\%), "searching for information" (42.1\%), "sharing information" (\%40.0), and "time passing" (34.6\%).

\section{Reliability, Exploratory and Confirmatory Factor Analysis}

Firstly, the reliability of the scales was separately tested.

After this analysis, an exploratory factor analysis was applied to determine the reliability and sampling adequacy of the scales. Due to the sample size, factor loads of 0.40 and above were considered. According to the exploratory factor analysis results, FIRO has five factors. Therefore, in the direction of the new factor structure, $\mathrm{H} 2$ and $\mathrm{H} 9 \mathrm{~b}$ and its sub-hypothesis were revised.

Meanwhile, according to the exploratory factor analysis results, online flow has five factors. Eliminated variables were the variables of the "mergence of action and awareness" and the "loss of self-consciousness" dimensions. Therefore, these two dimensions are out of the analysis.

Lastly, a confirmatory factor analysis was applied to determine whether the factors were compatible with the sample. The results of each analysis are shown in Table 3, and the fit index values are shown in Table 4. 


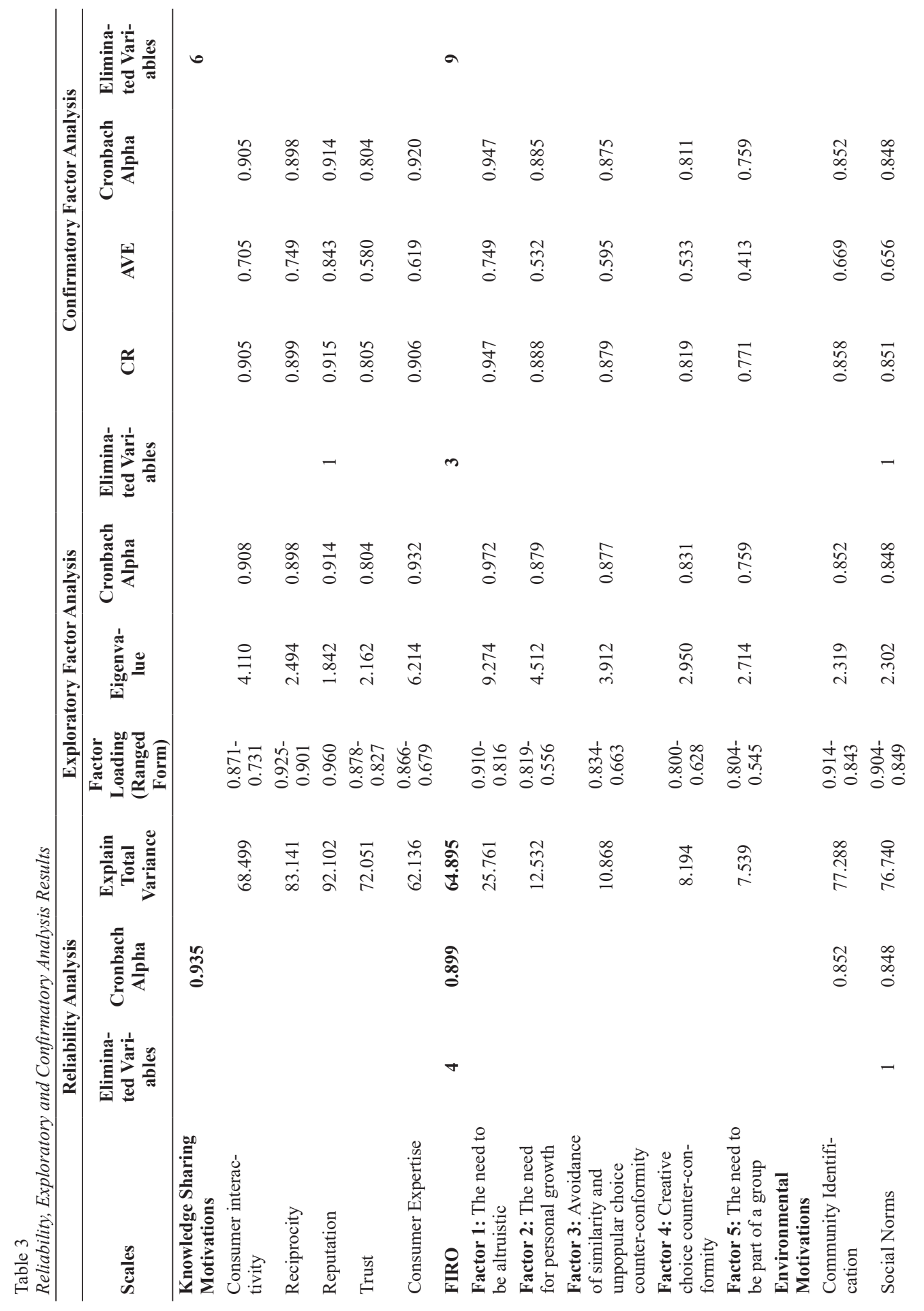




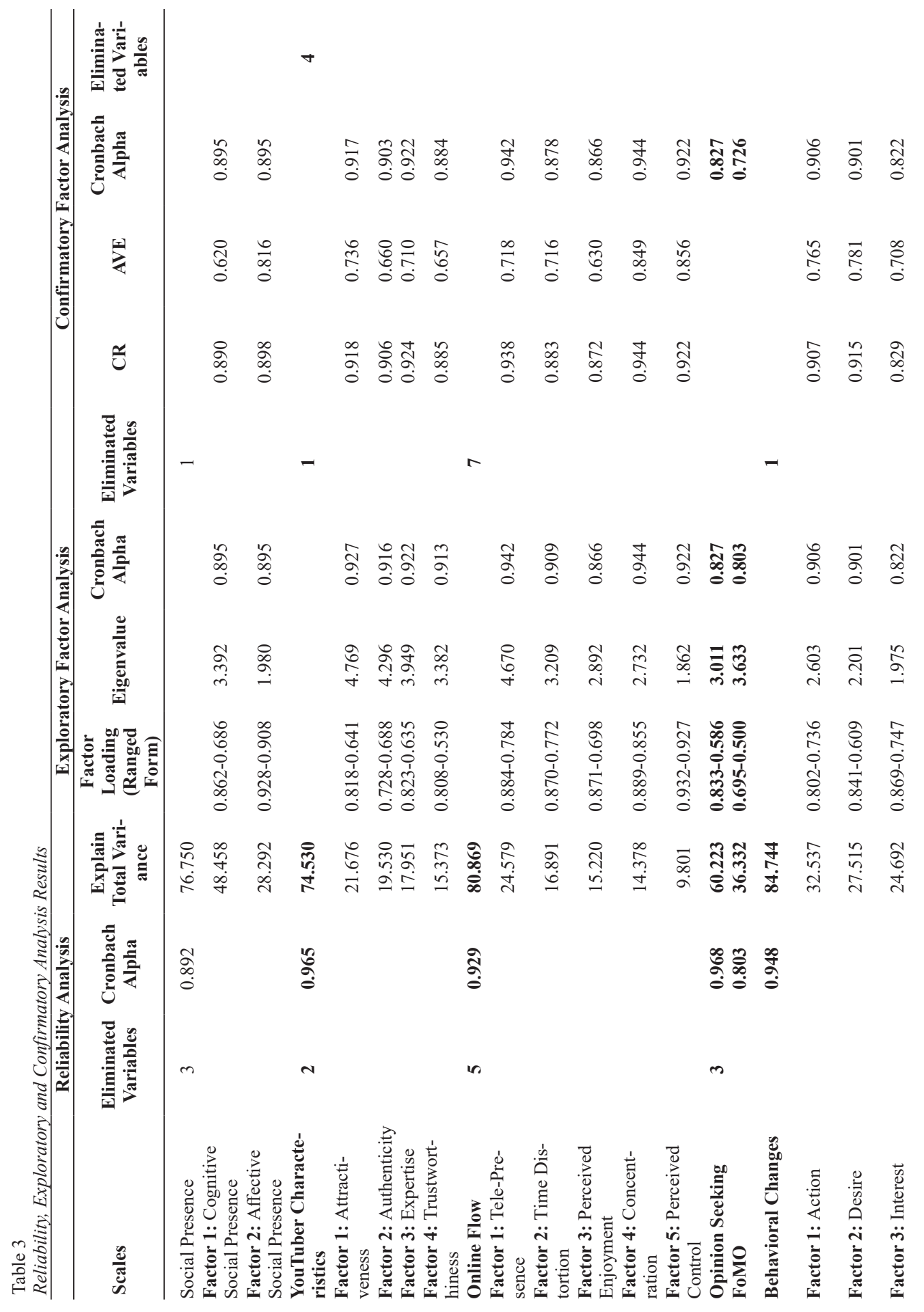


Table 4

Fit Index Values

\begin{tabular}{lcccccccc}
\hline Scales & $\begin{array}{c}\text { CMIN/ } \\
\text { df }\end{array}$ & GFI & AGFI & RMR & RMSEA & CFI & NNFI & NFI \\
\hline Knowledge Sharing Motivations & 3.030 & 0.923 & 0.895 & 0.043 & 0.063 & 0.960 & 0.952 & 0.942 \\
FIRO & 2.232 & 0.905 & 0.887 & 0.065 & 0.049 & 0.948 & 0.943 & 0.911 \\
Environmental Motivations & 4.294 & 0.933 & 0.894 & 0.056 & 0.080 & 0.956 & 0.940 & 0.944 \\
YouTuber Characteristics & 3.698 & 0.905 & 0.877 & 0.074 & 0.072 & 0.954 & 0.947 & 0.939 \\
Online Flow & 2.897 & 0.928 & 0.902 & 0.072 & 0.060 & 0.968 & 0.962 & 0.953 \\
Opinion Seeking & 4.957 & 0.984 & 0.941 & 0.020 & 0.087 & 0.984 & 0.960 & 0.980 \\
FoMO & 3.584 & 0.982 & 0.953 & 0.048 & 0.071 & 0.963 & 0.930 & 0.950 \\
Behavioral Changes & 2.698 & 0.980 & 0.955 & 0.015 & 0.057 & 0.992 & 0.987 & 0.988 \\
\hline
\end{tabular}

Generally, goodness of fit values criteria is as follows; CMIN/df is between the range of $1-5$, GFI value is $0.90<\mathrm{GFI}<0.95$, AGFI value is $0.85<\mathrm{AGFI}<0.90$, RMR value is $0.05 \leq \mathrm{RMR} \leq 0.08$, RMSEA value is $0.05<\mathrm{RMSEA}<0.08$, CFI value is $0.95<\mathrm{CFI}<0.97$, NNFI value is $0.95 \leq \mathrm{NNFI} \leq 0.97$, and NFI value is $0.90 \leq \mathrm{NFI} \leq 0.95$ (Schermelleh-Engel \& Moosbrugger, 2003). After the confirmatory factor analysis, it was seen that the goodness of fit values are at an acceptable level.

In addition to this, for each scale, Cronbach's alpha values exceed $0.70, \mathrm{CR}$ values exceed 0.70, and the AVE is generally larger than 0.50 (Hair, Black, Babin, \& Anderson, 2014). According to discriminant and convergent validity, all the scales are both reliable and valid.

\section{Research Model Testing}

The research model comprehensively addresses individual and environmental motivations as well as YouTuber characteristics and analyzes the behavioral changes of followers through online flow. For this reason, model testing was carried out over three different paths, and the results are shown below.

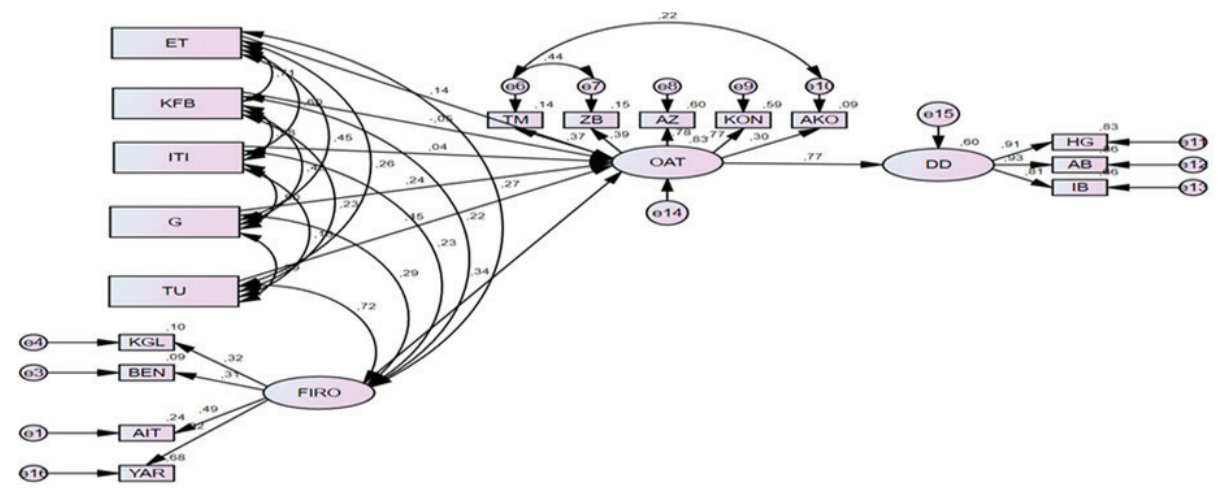

Figure 2. Path 1-The Effect of Individual Motivations on Online Flow and the Effect of Online Flow on Behavioral Changes of Followers 


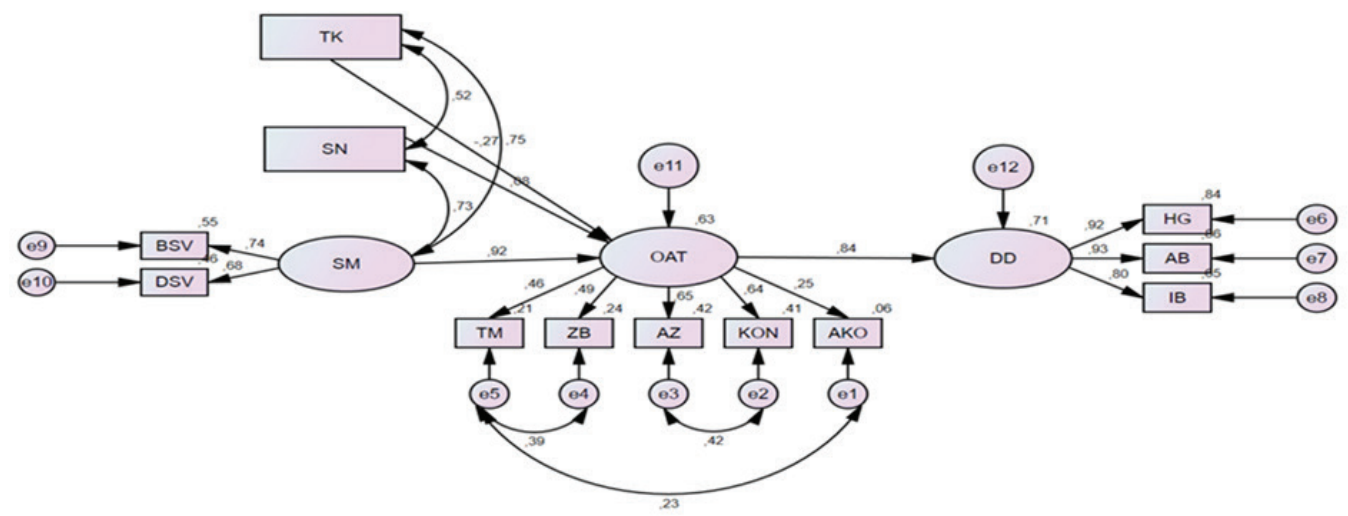

Figure 3. Path 2-The Effect of Environmental Motivations on Online Flow and the Effect of Online Flow on Behavioral Changes of Followers

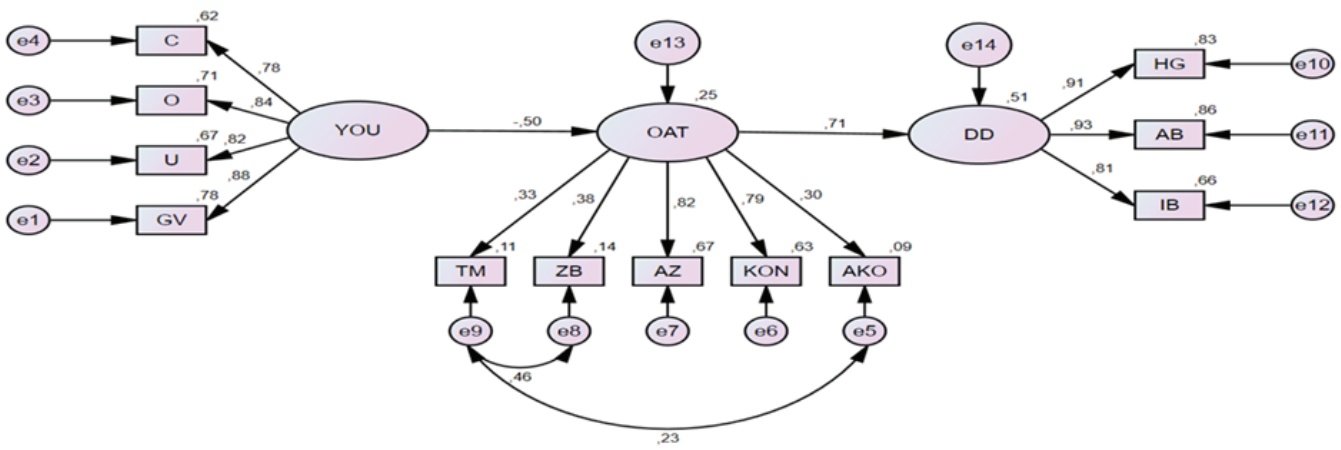

Figure 4. Path 3-The Effect of YouTuber Characteristics on Online Flow and the Effect of Online Flow on Behavioral Changes of Followers

The fit index for the path analyses is shown in Table 5.

Table 5

Fit Index Values of the Paths

\begin{tabular}{lcccccccc}
\hline \multicolumn{1}{c}{ Models } & \multicolumn{9}{c}{ Fit Index } \\
\hline & CMIN/df & GFI & AGFI & RMR & RMSEA & CFI & NNFI & NFI \\
\hline Path 1 & 3.626 & 0.922 & 0.881 & 0.059 & 0.071 & 0.936 & 0.913 & 0.914 \\
Path 2 & 4.699 & 0.931 & 0.882 & 0.048 & 0.084 & 0.944 & 0.920 & 0.931 \\
Path 3 & 4.607 & 0.946 & 0.915 & 0.055 & 0.071 & 0.962 & 0.950 & 0.949 \\
\hline
\end{tabular}

In the Path 1 analysis, it was seen that the model variables did not have fit values for the individual motivations step, and the recommended modifications were made. The "Altruism" 
dimension was excluded from the analysis, and $\mathrm{H} 2 \mathrm{~d}$ was rejected. After completing the recommended modifications, it was seen that the goodness of fit values are at an acceptable level. Path results are shown in Table 6.

Table 6

Paths Results

\begin{tabular}{|c|c|c|c|c|}
\hline \multicolumn{5}{|l|}{ PATH 1} \\
\hline Hypothesis & C.R. & S.R.W. & $\mathbf{p}$ & \\
\hline H1a & 3.082 & 0.145 & 0.002 & $\mathrm{H} 1 \mathrm{a}(+)$ \\
\hline $\mathrm{H} 1 \mathrm{~b}$ & -1.176 & -0.051 & 0.240 & H1b (-) \\
\hline $\mathrm{H} 1 \mathrm{c}$ & 1.060 & 0.043 & 0.289 & H1c (-) \\
\hline H1d & 5.243 & 0.238 & $* * *$ & H1d (+) \\
\hline H1e & 5.828 & 0.451 & $* * *$ & H1e $(+)$ \\
\hline $\mathrm{H} 2$ & 4.307 & 0.341 & $* * *$ & $\mathrm{H} 2(+)$ \\
\hline $\mathrm{H} 2 \mathrm{a}$ & & 0.493 & $* * *$ & $\mathrm{H} 2 \mathrm{a}(+)$ \\
\hline $\mathrm{H} 2 \mathrm{~b}$ & 5.688 & 0.307 & $* * *$ & $\mathrm{H} 2 \mathrm{~b}(+)$ \\
\hline $\mathrm{H} 2 \mathrm{c}$ & 9.791 & 0.824 & $* * *$ & $\mathrm{H} 2 \mathrm{c}(+)$ \\
\hline $\mathrm{H} 2 \mathrm{e}$ & 5.883 & 0.320 & $* * *$ & $\mathrm{H} 2 \mathrm{e}(+)$ \\
\hline $\mathrm{H} 7$ & 8.069 & 0.775 & $* * *$ & $\mathrm{H} 7(+)$ \\
\hline \multicolumn{5}{|l|}{ РATH 2} \\
\hline H3 & -2.290 & -0.273 & 0.022 & $\mathrm{H} 3(+)$ \\
\hline H4 & 0.827 & 0.085 & 0.408 & H4 (-) \\
\hline H5 & 3.599 & 0.915 & $* * *$ & $\mathrm{H} 5(+)$ \\
\hline $\mathrm{H} 5 \mathrm{a}$ & & 0.682 & & $\mathrm{H} 5 \mathrm{a}(+)$ \\
\hline $\mathrm{H} 5 \mathrm{~b}$ & 14.485 & 0.743 & $* * *$ & $\mathrm{H} 5 \mathrm{~b}(+)$ \\
\hline $\mathrm{H} 7$ & 5.121 & 0.844 & $* * *$ & $\mathrm{H} 7(+)$ \\
\hline \multicolumn{5}{|l|}{ РATH 3} \\
\hline H6 & -5.547 & -0.502 & $* * *$ & $\mathrm{H} 6(+)$ \\
\hline H6a & 23.202 & 0.816 & $* * *$ & $\mathrm{H} 6 \mathrm{a}(+)$ \\
\hline $\mathrm{H} 6 \mathrm{~b}$ & & 0.882 & & $\mathrm{H} 6 \mathrm{~b}(+)$ \\
\hline H6c & 21.789 & 0.785 & $* * *$ & $\mathrm{H} 6 \mathrm{c}(+)$ \\
\hline H6d & 24.467 & 0.844 & $* * *$ & H6d (+) \\
\hline $\mathrm{H} 7$ & 6.059 & 0.711 & $* * *$ & $\mathrm{H} 7(+)$ \\
\hline
\end{tabular}

C.R. $=\mathrm{t}$ value, S.R.W. $=$ Standardized Regression Weight, $\mathrm{p}<0.05, * * * \mathrm{p}<0.001$

Table Note: Accepted hypotheses have been shown with (+), rejected hypotheses have been shown with (-).

\section{Testing the Mediating Effect of Opinion Seeking}

Within the scope of the study, it was assumed that opinion-seeking has a mediating effect on the relationship between online flow and behavioral changes. The results are presented in Table 7. 
Table 7

Mediation Test Results

\begin{tabular}{|c|c|c|c|c|}
\hline & Fit Index Values & & & $\begin{array}{c}\text { Standardized Path } \\
\text { Coefficients }\end{array}$ \\
\hline Direct Model & $\begin{array}{c}\cdot \mathrm{CMIN} / \mathrm{df}=4.215 \\
\cdot \mathrm{GFI}=0.969 \\
\cdot \mathrm{AGFI}=0.926 \\
\cdot \mathrm{RMR}=0.053 \\
\cdot \mathrm{RMSEA}=0.079 \\
\cdot \mathrm{CFI}=0.976 \\
\cdot \mathrm{NNFI}=0.956 \\
\cdot \mathrm{NFI}=0.969\end{array}$ & Online Flow $\longrightarrow$ & $\begin{array}{c}\text { Behavioral } \\
\text { Changes of Follo- } \\
\text { wers }\end{array}$ & $\begin{array}{c}\cdot \text { S.R.W. }=0.712 \\
\cdot \text { C.R. }=6.027 \\
\cdot \mathrm{p}=* * *\end{array}$ \\
\hline $\begin{array}{l}\text { Mediation Mo- } \\
\text { del }\end{array}$ & $\begin{array}{c}\cdot \mathrm{CMIN} / \mathrm{df}=3.510 \\
\cdot \mathrm{GFI}=0.969 \\
\cdot \mathrm{AGFI}=0.933 \\
\cdot \mathrm{RMR}=0.050 \\
\cdot \mathrm{RMSEA}=0.070 \\
\cdot \mathrm{CFI}=0.975 \\
\cdot \mathrm{NNFI}=0.957 \\
\cdot \mathrm{NFI}=0.966\end{array}$ & Opinion Seeking $\longrightarrow$ & $\begin{array}{c}\text { Behavioral Changes } \\
\text { of Followers }\end{array}$ & $\begin{array}{c}\cdot \mathrm{S} . \mathrm{R} . \mathrm{W} .=0.291 \\
\cdot \mathrm{C} . \mathrm{R} .=4.456 \\
\cdot \mathrm{p}=* * * \\
\cdot \mathrm{S} . \mathrm{R} . \mathrm{W}=0.657 \\
\cdot \mathrm{C} . \mathrm{R} .=5.950 \\
\cdot \mathrm{p}=* * * \\
\cdot \mathrm{S} . \mathrm{R} . \mathrm{W} .=0.191 \\
\cdot \mathrm{C} . \mathrm{R} .=5.156 \\
\cdot \mathrm{p}=* * *\end{array}$ \\
\hline
\end{tabular}

\section{Sobel Test Results ${ }^{1}$}

Test Statistics $=2.019$, Standard Error $=0.027, p=0.04$

\section{Bootstrap Confidence Intervals}

Total Effect=0.013, Direct Effect=0.009, Indirect Effect=0.007, Bootstrap Confidence Interval=0.034-0.083

${ }^{1}$ http: //quantpsy.org/sobel, 2019, $* * * \mathrm{p}<0.001$.

According to the mediation model test results, it was seen that the variables in the mediating effect model are at an acceptable level. The relationship between online flow and followers' behavioral changes weakened with the addition of opinion-seeking. Thus, mediation conditions were provided, and partial mediating effects emerged (Baron \& Kenny, 1986). After the mediation test, the Sobel and Bootstrap Confidence Interval tests were performed. According to the results of both the Sobel and Bootstrap Confidence Intervals Tests, opinionseeking had a partial mediating effect. The H8 hypothesis was accepted.

\section{Testing the Moderating Role of FoMO}

An attempt to determine the moderator role of FoMO in the relationship between individual motivations and online flow was made. For the moderator variable test, participants were grouped as having a low FoMO (score below 3, N=174, M=2.98) and having a high FoMO (score above 3, $\mathrm{N}=228, \mathrm{M}=3.22$ ). After determining the group numbers, a moderator variable test was conducted. For this purpose, Excel macro was used as well as the AMOS program (http: //statwiki.kolobkreations.com, 2019). The moderating effect of FoMO is shown in Table 8 . 
Table 8

Moderating Effect of FoMO

\begin{tabular}{|c|c|c|c|}
\hline Participants with Low FoMO & C.R. & S.R.W. & p \\
\hline Online Flow<---Consumer Interactivity & 2.110 & 0.227 & $\mathbf{0 . 0 3 5}$ \\
\hline Online Flow $<---$ Reciprocity & -0.184 & -0.016 & 0.854 \\
\hline Online Flow<---Reputation & -0.559 & -0.044 & 0.576 \\
\hline Online Flow $<---$ Trust & 2.334 & 0.220 & $\mathbf{0 . 0 2 0}$ \\
\hline Online Flow $<---$ FIRO & 3.087 & 0.674 & 0.002 \\
\hline The need to be part of a group<---FIRO & & 0.658 & \\
\hline Creative choice counter-conformity<---FIRO & 7.619 & 0.811 & $* * *$ \\
\hline $\begin{array}{l}\text { Avoidance of similarity and unpopular choice counter- } \\
\text { conformity <---FIRO }\end{array}$ & 3.479 & 0.301 & $* * *$ \\
\hline The need for personal growth<---FIRO & 2.528 & 0.216 & 0.011 \\
\hline Tele-presence<---Online Flow & & 0.283 & \\
\hline Time Distortion<----Online Flow & 3.756 & 0.492 & $* * *$ \\
\hline Perceived Enjoyment<---Online Flow & 3.483 & 0.882 & $* * *$ \\
\hline Concentration<----Online Flow & 3.400 & 0.804 & $* * *$ \\
\hline \multicolumn{4}{|l|}{ Participants with High FoMO } \\
\hline Online Flow<---Consumer Interactivity & 0.928 & 0.075 & 0.354 \\
\hline Online Flow<---Reciprocity & -0.631 & -.0048 & 0.528 \\
\hline Online Flow $<---$ Reputation & -0.621 & -0.044 & 0.535 \\
\hline Online Flow $<---$ Trust & 4.222 & 0.407 & $* * *$ \\
\hline Online Flow<---FIRO & 3.870 & 0.571 & $* * *$ \\
\hline The need to be part of a group<---FIRO & & 0.397 & \\
\hline Creative choice counter-conformity<---FIRO & 5.148 & 0.897 & $* * *$ \\
\hline $\begin{array}{l}\text { Avoidance of similarity and unpopular choice counter- } \\
\text { conformity <---FIRO }\end{array}$ & 3.836 & 0.342 & $* * *$ \\
\hline The need for personal growth $<---$ FIRO & 4.361 & 0.423 & $* * *$ \\
\hline Tele-presence<---Online Flow & & 0.408 & \\
\hline Time Distortion<----Online Flow & 2.838 & 0.176 & 0.005 \\
\hline Perceived Enjoyment <---Online Flow & 5.162 & 0.848 & $* * *$ \\
\hline Concentration<----Online Flow & 5.505 & 0.796 & $* * *$ \\
\hline
\end{tabular}

C.R. $=$ t value, S.R.W. $=$ Standardized Regression Weight, $\mathrm{p}<0.05, * * * \mathrm{p}<0.001$

In the moderation analysis, the model variables did not have fit values, and the recommended modifications were made. The "consumer expertise" and "perceived control" dimensions were excluded from the analysis. After these modifications, it was seen that the goodness of fit values were at an acceptable level. The Fit indexes are $\mathrm{CMIN} / \mathrm{df}=1.750, \mathrm{RMR}=0.06$, $\mathrm{RMSEA}=0.043, \mathrm{GFI}=0.943, \mathrm{AGFI}=0.891, \mathrm{NFI}=0.918, \mathrm{NNFI}=0.939$, and $\mathrm{CFI}=0.962$.

In terms of participants with low FoMO, there are statistically significant relationships between the following variables: consumer interactivity and online flow (Estimate $=0.060 ; \mathrm{t}$ value $=2.110)$, trust and online flow $($ Estimate $=0.075 ; \mathrm{t}$ value $=2.334)$, and FIRO and online flow $($ Estimate $=0.336$; $\mathrm{t}$ value $=3.087)$.

In terms of participants with high FoMO, there are statistically significant relationships between the following variables: trust and online flow (Estimate $=0.188$; $t$ value $=4.222$ ) 
and FIRO and online flow $($ Estimate $=0.881 ; \mathrm{t}$ value $=3.870)$. The chi-square difference test results are presented in Table 9.

Table 9

Chi-Square Differences Test Results

\begin{tabular}{|c|c|c|c|c|c|}
\hline & \multicolumn{2}{|c|}{ High } & \multicolumn{3}{|c|}{ Low } \\
\hline & Estimates & p & Estimates & $\mathbf{p}$ & z-score \\
\hline $\begin{array}{l}\text { Online Flow<---Consumer Inte- } \\
\text { ractivity }\end{array}$ & 0.027 & 0.354 & 0.06 & 0.035 & 0.788 \\
\hline Online Flow<---Reciprocity & -0.018 & 0.528 & -0.005 & 0.854 & 0.359 \\
\hline Online Flow<---Reputation & -0.015 & 0.535 & -0.011 & 0.576 & 0.118 \\
\hline Online Flow<---Trust & 0.188 & $* * *$ & 0.075 & 0.02 & $-2.058 * *$ \\
\hline Online Flow<---FIRO & 0.881 & $* * *$ & 0.336 & 0.002 & $-2.161 * *$ \\
\hline $\begin{array}{l}\text { The need to be part of a group }<- \\
\text {--FIRO }\end{array}$ & 1 & & 1 & & \\
\hline $\begin{array}{l}\text { Creative choice counter- } \\
\text { conformity<---FIRO }\end{array}$ & 3.005 & $* * *$ & 1.263 & $* * *$ & \\
\hline $\begin{array}{l}\text { Avoidance of similarity and } \\
\text { unpopular choice counter-con- } \\
\text { formity <---FIRO }\end{array}$ & 1.247 & $* * *$ & 0.511 & $* * *$ & \\
\hline $\begin{array}{l}\text { The need for personal growth }<- \\
\text {--FIRO }\end{array}$ & 0.88 & $* * *$ & 0.261 & 0.011 & \\
\hline Tele-presence<---Online Flow & 1 & & 1 & & \\
\hline Time Distortion<---Online Flow & 0.49 & 0.005 & 1.846 & $* * *$ & \\
\hline $\begin{array}{l}\text { Perceived Enjoyment <---Online } \\
\text { Flow }\end{array}$ & 1.788 & $* * *$ & 2.559 & $* * *$ & \\
\hline Concentration<---Online Flow & 1.835 & $* * *$ & 2.993 & $* * *$ & \\
\hline
\end{tabular}

The results of the moderator variable test showed that hypotheses H9, H9a and subhypothesis H9a.d were accepted. However, H9a.a, H9a.b, H9a.c, and H9a.e were rejected. In addition to this, H9b and sub-hypotheses H9b.a, H9b.b, H9b.c, and H9b.e were accepted, while H9b.d was rejected.

\section{Conclusions}

Within the scope of the research, a comprehensive model was proposed by bringing together variables that had not been studied before. The findings obtained are as follows:

In terms of individual motivations, consumer interactivity, trust, and consumer expertise have a positive effect on online flow. According to results, as interactivity level increases, the knowledge-sharing tendency also increases. Therefore, the two-way communication between YouTubers and followers accelerates the online flow process. For trust, it can be stated that if the trust of the followers in both each other and in YouTubers increases, knowledge-sharing increases, and followers are involved in the online flow. Lastly, in regards to consumer expertise, individuals will spend more time in the mediated environment to learn more and 
contribute to the process, but as for the reciprocity and reputation dimensions, they have no effect on online flow.

Meanwhile personal growth, avoidance of similarity and unpopular choice counter-conformity, creative choice counter-conformity, and the need to be part of a group have a positive effect on online flow. For personal growth, consumers who are characterized with intense opinion-seeking consume more video content to ensure personal growth and experience all stages of the online consumer behavior decision making process. Followers have an avoidance of similarity and want to be different from others. Therefore, they tend to consume video content which emphasizes on difference. Due to creative choice counter-conformity, they prefer products which are accepted by the society. At this point, the need for uniqueness depends on different usage and applications and brand preference. Finally, in terms of the need to be part of a group, they want to consume the same content and applications as the online community. In this direction, for all individual motivations, the online flow process is accelerated, and the process ends with behavioral change.

In terms of environmental motivations, community identification has a negative effect on online flow whereas affective and cognitive social presences have a positive effect. However, social norms have no effect.

For community identification and social norms, individuals follow a YouTuber and video content. However, they do not consider themselves as part of the community. Followers do not act with a community identity, and this situation causes a negative effect on the online flow. Similarly, this situation does not lead to a behavioral change in terms of social norms. This is because the online consumer is more of an individual and independent. For social presence, it is seen that considering important to the individual both affectively and cognitively, and the community will reveal online flow and behavioral changes.

YouTuber characteristics have a negative effect on online flow. At this point, individuals follow YouTubers and care about their characteristics, but these are not the unique factor in online flow. However, it was seen that the subdimensions of YouTuber characteristics have a positive effect.

Opinion-seeking has a partial mediator role in the relationship between online flow and behavioral changes. Due to followers' need for information and the importance of information, online flow has an effect on opinion-seeking, and opinion-seeking has an effect on behavioral change.

Finally, the results demonstrate that high FoMO individuals have more trust in the information shared by YouTubers. Meanwhile, individuals with high FoMO have more need to be part of a group, need for creative choices, and need for personal growth. However, they avoid 
similarity less. Finally, these individuals have fears of missing out, of not being informed, and of falling behind other individuals. For this reason, personal growth needs are also high.

\section{Implications}

According to findings, it is seen that individuals attach importance to the knowledge-sharing motivation. YouTubers can concentrate more on videos that explain product promotions, content, and usage. This proposal can also be evaluated in terms of community identification.

Knowledge-sharing between followers has essential for an effective communication process. Therefore, effective content production can be supported with applications such as augmented reality. It is important to offer followers quality content which can draw attention in terms of video structure and fiction. YouTubers can enable their followers to get involved in their content production and sharing process. Also, when businesses can present video content which followers can talk about and which trigger the discussion and commentary process about said video content, they will be able to convert the interaction process to online flow. The increasing number of shares and likes will bring new followers, comments, and popularity at that rate.

To increase the sense of trust in the community, it is necessary to provide effective feedback to the followers, to get feedback from them, and to report the satisfaction or dissatisfaction under the heading "from you." YouTubers should demonstrate that they are not supported by any brand and are neutral to increase the level of trust from the followers.

Today, customers are connecting with brands to which these customers can access, and the brands can access their customers. Therefore, the consumer should be included in the cocreation process. The emphasis on expertise can be brought to the forefront with "you can improve" competitions.

YouTubers are virtual opinion leaders. However, it should not be ignored that expert consumers also have the potential to become opinion leaders. Businesses can make these people as brand ambassadors who can support the process of creating their own followers.

Followers care about their personal growth. In this sense, "How did I do it?", "How is it done?", and "Request videos from followers" videos will have a significant effect.

Followers have an avoidance of similarity. For these consumer groups, "limited" can be a strategy. An "emphasis on uniqueness and different from the others," "customized products/ messages," and a "perception of high quality" are among the strategies that can be applied. With this strategy, individuals with a high FoMO can also be satisfied. Market segmentation is another strategy that can be recommended. Meanwhile this proposal can also be evaluated in terms of community identification, and one-to-one marketing practices might be preferred. 
In terms of the need to be part of a group, YouTube is a platform which emphasizes on community culture. YouTubers tend to share their everyday lives. This can make practitioners' work easier.

Today, individuals are active in two distinct worlds - the real world and the virtual world. For this reason, businesses should effectively integrate them. This can be achieved by creating avatars and developing augmented reality and 3D applications for social presence.

In the online flow process, YouTuber characteristics are not the sole factor. YouTubers should clearly introduce themselves to their followers to provide effective and accurate communication. YouTubers can determine which characteristic stands out in the eyes of their followers and constitute differentiation strategies.

Influencers have considerable importance in the sense of brand storytelling. Therefore, marketers and professionals should look for a way to use these individuals in brand dialogues.

In order to influence opinion-seekers, virtual experiences, testing products, sending a prototype of new products to YouTubers, the use of a product by a YouTuber in a video, and applying for in-video advertising strategies can be used. These applications are valuable for individuals who have a high FoMO as well as individuals who are connected to their electronic devices and can be considered as an "innovator" consumer group. For this reason, it is necessary to act quickly in the communication of these individuals and to make and emphasize this innovation, and behavioral changes can be achieved by creating the perception of "being special."

\section{Limitations and Future Studies}

This study was carried out Istanbul, and within the scope of the research, a particular product group, brand, or YouTuber was not focused on; merely a specific segment was selected. Limitations of the study are that a product/brand group or YouTubers in general were not evaluated since the study was established on a specific segment and city.

In future studies, personality, lifestyles, values, expectations, and different motivational processes can be included in the model. Purchasing and decision-making styles which are active in the virtual world and in online flow can be discussed. Furthermore, opinion leadership and opinion-passing behaviors can be added to the model. Through the consumer-oriented model, consumer characteristics can be determined, and this can create consumer profiles. Similarly, a YouTube consumer inventory can be designed for YouTubers, and market segmentation studies can be carried out. How the model will give results in terms of different social media tools and vlog fields can be investigated, and a comparative study can be carried out. 
Peer-review: Externally peer-reviewed.

Author Contributions: Conception/Design of study: F.G.D., S.Ü.; Data Analysis/Interpretation: F.G.D., S.Ü.; Drafting Manuscript: F.G.D.; Critical Revision of Manuscript: F.G.D., S.Ü.; Final Approval and Accountability: : F.G.D., S.Ü.

Conflict of Interest: The authors have no conflict of interest to declare.

Grant Support: The authors declared that this study has received no financial support.

\section{References}

Agarwal, R., \& Karahanna, E. (2000). Time flies when you're having fun: Cognitive absorption and beliefs about information technology usage. MIS Quarterly, 24(4), 665-694. https://doi.org/10.2307/3250951.

Alba, J. W., \& Hutchinson, J. W. (1987). Dimensions of consumer expertise. Journal of Consumer Research, 13(4), 411-454. https://doi.org/10.1086/209080.

Ananda, A. F., \& Wandebori, H. (2016). The impact of drugstore makeup product reviews by beauty vlogger on YouTube towards purchase intention by undergraduate students in Indonesia. In International Conference on Ethics of Business, Economics, and Social Science, 3(1), 264-272.

Baron, R. M., \& Kenny, D. A. (1986). The moderator-mediator variable distinction in social psychological research: Conceptual, strategic, and statistical considerations. Journal of Personality and Social Psychology, 51(6), 1173. https://doi.org/10.1037/0022-3514.51.6.1173.

Bhaduri, G., \& Stanforth, N. (2016). Evaluation of absolute luxury: Effect of cues, consumers' need for uniqueness, product involvement and product knowledge on expected price. Journal of Fashion Marketing and Management: An International Journal, 20(4), 471-486. https://doi.org/10.1108/JFMM-122015-0095.

Bridges, E., \& Florsheim, R. (2008). Hedonic and utilitarian shopping goals: The online experience. Journal of Business Research, 61(4), 309-314. https://doi.org/10.1016/j.jbusres.2007.06.017.

Cao, Y. (2015). Research on consumption psychology and consumption behaviors in the mobile internet era. 3rd International Conference on Management Science, Education Technology, Arts, Social Science and Economics (MSETASSE 2015), 5-8. https://doi.org/10.2991/msetasse-15.2015.2.

Chang, H.H., \& Chuang, S-S. (2011). Social capital and individual motivations on knowledge sharing: Participant involvement as a moderator. Information \& Management, 48, 9-18. https://doi.org/10.1016/j. im.2010.11.001.

Chapple, C., \& Cownie, F. (2017). An investigation into viewers' trust in and response towards disclosed paid-for-endorsements by YouTube lifestyle vloggers. Journal of Promotional Communications, 5(2), 110-136.

Cheung, C. M., Xiao, B., \& Liu, I. L. (2012). The impact of observational learning and electronic word of mouth on consumer purchase decisions: The moderating role of consumer expertise and consumer involvement. 2012 45th Hawaii International Conference on System Sciences, 3228-3237. doi: 10.1109/ HICSS.2012.570.

Choi, J.H. (2015). Putting the social into social network sites: A knowledge sharing perspective (Doctoral dissertation). Available from ProQuest Dissertations and Theses database. (UMI No. 3702063).

Chu, S-C., \& Kim, Y. (2011). Determinants of consumer engagement in electronic word-of-mouth (eWOM) in social networking sites. International Journal of Advertising, 30(1), 47-75. https://doi.org/10.2501/ IJA-30-1-047-075. 
Esteban-Millat, I., Martínez-López, F. J., Huertas-García, R., Meseguer, A., \& Rodríguez-Ardura, I. (2014). Modelling students' flow experiences in an online learning environment. Computers \& Education, 71, 111-123. https://doi.org/10.1016/j.compedu.2013.09.012.

Flynn, L.R., Goldsmith, R.E., \& Eastman, J.K. (1996). Opinion leaders and opinion seekers: Two new measurement scales. Journal of the Academy of Marketing Science, 24(2), 137-147. https://doi. org/10.1177/0092070396242004.

Franchina, V., Vanden Abeele, M., van Rooij, A., Lo Coco, G., \& De Marez, L. (2018). Fear of missing out as a predictor of problematic social media use and phubbing behavior among Flemish adolescents. International Journal of Environmental Research and Public Health, 15(2319), 1-18. https://doi.org/10.3390/ ijerph15102319.

García-Rapp, F. (2016). The digital media phenomenon of YouTube beauty gurus: The case of Bubzbeauty. International Journal of Web Based Communities (IJWBC), 12(4), 360-375. https://doi.org/10.1504/ IJWBC.2016.080810.

Gomes, D., Sales, R., Cavalcante, F. \& Carvalho, C. (2014). Watch decide and share: The role of web video information during the buying decision process. International Journal of Video \& Image Processing and Network Security IJVIPNS-IJENS, 14(5), 7-18.

Guo, Y. (2004). Flow in internet shopping: A validity study and an examination of a model specifying antecedents and consequences of flow (Doctoral dissertation). Available from ProQuest Dissertations and Theses database. (UMI No. 3157431).

Hair, J. F., Black, W. C., Babin, B. J., \& Anderson, R. E. (2014). Multivariate Data Analysis: Pearson New International Edition, London: Pearson Education Limited.

Ho, J. Y. C., \& Dempsey, M. (2010). Viral marketing: Motivations to forward online content. Journal of Business Research, 63, 1000-1006. https://doi.org/10.1016/j.jbusres.2008.08.010.

Hoffman, D. L., \& Novak T. P. (1996). Marketing in hypermedia computer-mediated environments: Conceptual foundations. Journal of Marketing, 60(3), 50-68. https://doi.org/10.1177/002224299606000304.

Hochanadel, C. E. (2014). Motivations for engaging in electronic word of mouth in a social networking setting (Doctoral dissertation). Available from ProQuest Dissertations and Theses database. (UMI No. 3648516).

Hsu, C. L., Chang, K. C., \& Chen, M. C. (2012). Flow experience and internet shopping behavior: Investigating the moderating effect of consumer characteristics. Systems Research and Behavioral Science, 29(3), 317-332. https://doi.org/10.1002/sres.1101.

Hsu, C. L., \& Lin, J. C. C. (2008). Acceptance of blog usage: The roles of technology acceptance, social influence and knowledge sharing motivation. Information \& Management, 45(1), 65-74. https://doi. org/10.1016/j.im.2007.11.001.

$\mathrm{Hu}, \mathrm{X}$. (2015). Assessing source credibility on social media-an electronic word-of-mouth communication perspective (Doctoral dissertation). Available from ProQuest Dissertations and Theses database. (UMI No. 3710218).

Huang, J., Chen, R., \& Wang, X. (2012). Factors influencing intention to forward short internet videos. Social Behavior and Personality: An International Journal, 40(1), 5-14. https://doi.org/10.2224/sbp.2012.40.1.5.

Huguenel, B. M. (2017). Fear of missing out: A moderated mediation approach to social media use (Master dissertation). USA: Loyola University. Available from ProQuest Dissertations and Theses database. (UMI No. 10637321). 
Jadin, T., Gnambs, T., \& Batinic, B. (2013). Personality traits and knowledge sharing in online communities. Computers in Human Behavior, 29(1), 210-216. https://doi.org/10.1016/j.chb.2012.08.007.

Jenster, N.P. (2010). Leadership impact on motivation, cohesiveness and effectiveness in virtual teams: A FIRO perspective (Doctoral dissertation). Available from ProQuest Dissertations and Theses database. (UMI No. 3471610).

Jin, J., Li, Y. L., Zhong, X., \& Zhai, L. (2015). Why users contribute knowledge to online communities: An empirical study of an online social Q\&A community. Information \& Management, 52, 840-849. https:// doi.org/10.1016/j.im.2015.07.005.

Kang, J-Y. M., Johnson, K.K.P. \& Wu, J. (2014). Consumer style inventory and intent to social shop online for apparel using social networking sites. Journal of Fashion Marketing and Management, 18(3), 301320. https://doi.org/10.1108/JFMM-09-2012-0057.

Kaur, P., Dhir, A., Chen, S. \& Rajala, R. (2016). Flow in context: Development and validation of the flow experience instrument for social networking. Computers in Human Behavior, 59, 358-367. https://doi. org/10.1016/j.chb.2016.02.039.

Khan, M. L. (2017). Social media engagement: What motivates user participation and consumption on YouTube? Computers in Human Behavior, 66, 236-247. https://doi.org/10.1016/j.chb.2016.09.024.

Kim, S. S., Lee, J., \& Prideaux, B. (2014). Effect of celebrity endorsement on tourists' perception of corporate image, corporate credibility and corporate loyalty. International Journal of Hospitality Management, 37, 131-145. https://doi.org/10.1016/j.ijhm.2013.11.003.

Kim, J., Song, H., \& Luo, W. (2016). Broadening the understanding of social presence: Implications and contributions to the mediated communication and online education. Computers in Human Behavior, 65, 672-679. https://doi.org/10.1016/j.chb.2016.07.009.

Koufaris, M. (2002). Applying the technology acceptance model and flow theory to online consumer behavior. Information Systems Research, 13(2), 205-223. https://doi.org/10.1287/isre.13.2.205.83.

Ku, Y. C., Wei, C. P., \& Hsiao, H. W. (2012). To whom should I listen? Finding reputable reviewers in opinion-sharing communities. Decision Support Systems, 53(3), 534-542. https://doi.org/10.1016/j. dss.2012.03.003.

Kurtuluş, K. (2004). Pazarlama Araştırmaları. İstanbul: Literatür Yayıncılık.

Lai, H-M., \& Chen, T. T. (2014). Knowledge sharing in interest online communities: A comparison of posters and lurkers. Computers in Human Behavior, 35, 295-306. https://doi.org/10.1016/j.chb.2014.02.004.

Leary, M. R., Kelly, K. M., Cottrell, C. A., \& Schreindorfer, L.S. (2013). Construct validity of the need to belong scale: Mapping the nomological network. Journal of Personality Assessment, 95(6), 610-624. https://doi.org/10.1080/00223891.2013.819511.

Lee, D., Park, Y. J., Kim, J., Kim, J., \& Moon, J. (2011). Understanding music sharing behaviour on social network services. Online Information Review, 35(5), 716-733. https://doi.org/10.1108/14684521111176462.

Lee, J. E., \& Watkins, B. (2016). YouTube vloggers' influence on consumer luxury brand perceptions and intentions. Journal of Business Research, 69, 5753-5760. https://doi.org/10.1016/j.jbusres.2016.04.171.

Liu, C-C. (2017). A model for exploring players flow experience in online games. Information Technology \& People, 30(1), 139-162. https://doi.org/10.1108/ITP-06-2015-0139.

Liu, L., Cheung, C. M., \& Lee, M. K. (2016). An empirical investigation of information sharing behavior on social commerce sites. International Journal of Information Management, 36(5), 686-699. https://doi. org/10.1016/j.ijinfomgt.2016.03.013.

Liu, H., Chu, H., Huang, Q., \& Chen, X. (2016). Enhancing the flow experience of consumers in China through interpersonal interaction in social commerce. Computers in Human Behavior, 58, 306-314. https:// doi.org/10.1016/j.chb.2016.01.012. 
Liu, H. J.\& Shiue, Y. C. (2014). Influence of Facebook game players' behavior on flow and purchase intention. Social Behavior and Personality: An International Journal, 42(1), 125-133. https://doi.org/10.2224/ sbp.2014.42.1.125.

Ma, M., \& Agarwal, R. (2007). Through a glass darkly: Information technology design, identity verification, and knowledge contribution in online communities. Information Systems Research, 18(1), 42-67. https:// doi.org/10.1287/isre.1070.0113.

Ma, W. W., \& Chan, A. (2014). Knowledge sharing and social media: altruism, perceived online attachment motivation, and perceived online relationship commitment. Computers in Human Behavior, 39, 51-58. https://doi.org/10.1016/j.chb.2014.06.015.

Moulard, J. G., Garrity, C. P. \& Rice, D. H. (2015). What makes a human brand authentic? Identifying the antecedents of celebrity authenticity. Psychology \& Marketing, 32(2), 173-186. https://doi.org/10.1002/ mar.20771.

Novak, T. P., Hoffman, D. L., \& Yung, Y. F. (2000). Measuring the customer experience in online environments: A structural modeling approach. Marketing Science, 19(1), 22-42. https://doi.org/10.1287/ mksc.19.1.22.15184.

Oberst, U., Wegmann, E., Stodt, B., Brand, M. \& Chamarro, A. (2017). Negative consequences from heavy social networking in adolescents: The mediating role of fear of missing out. Journal of Adolescence, 55, 51-60. https://doi.org/10.1016/j.adolescence.2016.12.008.

Ohanian, R. (1990). Construction and validation of a scale to measure celebrity endorsers' perceived expertise, trustworthiness and attractiveness. Journal of Advertising, 19, 39-52. https://doi.org/10.1080/00913 367.1990 .10673191$.

Pelet, J. É., Ettis, S., \& Cowart, K. (2017). Optimal experience of flow enhanced by telepresence: Evidence from social media use. Information \& Management, 54(1), 115-128. https://doi.org/10.1016/j. im.2016.05.001.

Przybylski, A. K., Murayama, K., DeHaan, C. R., \& Gladwell, V. (2013). Motivational, emotional, and behavioral correlates of fear of missing out. Computers in Human Behavior, 29, 1841-1848. https://doi. org/10.1016/j.chb.2013.02.014.

Quantpsy. (2019, March 17). Retrieved from http://quantpsy.org/sobel.

Robitschek, C. (1998). Personal growth initiative: The construct and its measure. Measurement and Evaluation in Counseling and Development, 30(4), 183-198. https://doi.org/10.1080/07481756.1998.12068941.

Rose, P. \& Kim, J.H. (2011). Self-monitoring, opinion leadership and opinion seeking: A socio motivational approach. Current Psychology, 30, 203-214. DOI 10.1007/s12144-011-9114-1.

Ruvio, A., Shoham, A., \& Brenčič, M. M. (2008). Consumers' need for uniqueness: Short-form scale development and cross-cultural validation. International Marketing Review, 25(1), 33-53. https://doi.org/10.1 108/02651330810851872.

Safa, N. S., \& Ismail, M. A. (2013). A customer loyalty formation model in electronic commerce. Economic Modelling, 35, 559-564. https://doi.org/10.1016/j.econmod.2013.08.011.

Schermelleh-Engel, K., \& Moosbrugger, H. (2003). Evaluating the fit of Structural Equation Models: Tests of significance and descriptive goodness-of-fit measures. Methods of Psychological Research Online, $8(2), 23-74$.

Shen, A., Lee, M. K., Cheung, C. M., \& Chen, H. (2010). Gender differences in intentional social action: Weintention to engage in social network-facilitated team collaboration. Journal of Information Technology, 25(2), 152-169. https://doi.org/10.1057/jit.2010.12. 
Shen, K. N. \& Khalifa, M. (2008). Exploring multidimensional conceptualization of social presence in the context of online communities. International Journal of Human-Computer Interaction, 24(7), 722-748. https://doi.org/10.1080/10447310802335789.

Shen, K.N. \& Khalifa, M. (2012). System design effects on online impulse buying. Internet Research, 22(4), 396-425. https://doi.org/10.1108/10662241211250962.

Shim, I.S. (2012). Enhancing brand loyalty through brand experience: Application of online flow theory (Doctoral Dissertation). Available from ProQuest Dissertations and Theses database. (UMI No. 3520451).

Sohn, Y. (2005). Opinion leaders and seekers in online brand communities: Centered on Korean digital camera brand communities (Master dissertation). Available from ProQuest Dissertations and Theses database. (UMI No. 1430471).

Song, S. Y., Cho, E., \& Kim, Y. K. (2017). Personality factors and flow affecting opinion leadership in social media. Personality and Individual Differences, 114, 16-23. https://doi.org/10.1016/j.paid.2017.03.058.

Statwiki. (2019, March 16). Retrieved from http://statwiki.kolobkreations.com.

Steuer, J. (1992). Defining virtual reality: Dimensions determining telepresence. Journal of Communication, 42(4), 73-93. https://doi.org/10.1111/j.1460-2466.1992.tb00812.x.

Tang, Q., Zhao, X., Liu, S. (2016). The effect of intrinsic and extrinsic motivations on mobile coupon sharing in social network sites: The role of coupon proneness. Internet Research, 26(1), 101-119. https://doi. org/10.1108/IntR-05-2014-0136.

Teng, S., Khong, K.W., Goh, W.W. \& Chong, A.Y.L. (2014). Examining the antecedents of persuasive E-WOM messages in social media. Online Information Review, 38(6), 746-768. https://doi.org/10.1108/ OIR-04-2014-0089.

Thomas, R.A., West, R.E. \& Borup, J. (2017). An analysis of instructor social presence in online text and asynchronous video feedback comments. Internet and Higher Education, 33, 61-73. https://doi. $\operatorname{org} / 10.1016 / j$.iheduc.2017.01.003.

van Noort, G., Voorveld, H. A. \& Van Reijmersdal, E. A. (2012). Interactivity in brand web sites: Cognitive, affective, and behavioral responses explained by consumers' online flow experience. Journal of Interactive Marketing, 26(4), 223-234. https://doi.org/10.1016/j.intmar.2011.11.002.

Wang, Y. (2014). Fashion meets Twitter: Does the source matter? Perceived message credibility, interactivity and purchase intention (Master Dissertation). Available from ProQuest Dissertations and Theses database. (UMI No. 1565545).

Wang, E. S. T., \& Chen, L. S. L. (2012). Forming relationship commitments to online communities: The role of social motivations. Computers in Human Behavior, 28(2), 570-575. https://doi.org/10.1016/j. chb.2011.11.002.

Wang, L. C. \& Hsiao, D. F. (2012). Antecedents of flow in retail store shopping. Journal of Retailing and Consumer Services, 19(4), 381-389. https://doi.org/10.1016/j.jretconser.2012.03.002.

Wang, D., Oppewal, H., \& Thomas, D. (2017). Anticipated embarrassment due to social presence withholds consumers from purchasing products that feature a lucky charm. European Journal of Marketing, 51(9/10), 1612-1630. https://doi.org/10.1108/EJM-02-2015-0087.

Wei, P-S., \& Lu, H-P. (2013). An examination of the celebrity endorsements and online customer reviews influence female consumers' shopping behavior. Computers in Human Behavior, 29, 193-201. https://doi. org/10.1016/j.chb.2012.08.005.

Whiting, A., \& Williams, D. (2013). Why people use social media: A uses and gratifications approach. Qualitative Market Research: An International Journal, 16(4), 362-369. https://doi.org/10.1108/QMR06-2013-0041. 
Wu, G., Hu, X., \& Wu, Y. (2010). Effects of perceived interactivity, perceived web assurance and disposition to trust on initial online trust. Journal of Computer-Mediated Communication, 16, 1-26. https://doi. org/10.1111/j.1083-6101.2010.01528.x.

Yan, Z., Wang, T., Chen, Y., \& Zhang, H. (2016). Knowledge sharing in online health communities: A social exchange theory perspective. Information \& Management, 53, 643-653. https://doi.org/10.1016/j. im.2016.02.001.

Yang, C., Hsu, Y-C., \& Tan, S. (2010). Predicting the determinants of users' intentions for using YouTube to share video: Moderating gender effects. Cyberpsychology, Behavior, and Social Networking, 13(2), 141152. https://doi.org/10.1089/cyber.2009.0105.

Yang, K-C., Huang, C-H., Yang, C. \& Yang, S.Y. (2017). Consumer attitudes toward online video advertisement: YouTube as a platform. Kybernetes, 46(5), 840-853. https://doi.org/10.1108/K-03-2016-0038.

Yin, F-S., Liu, M-L. \& Lin, C-P. (2015). Forecasting the continuance intention of social networking sites: Assessing privacy risk and usefulness of technology. Technological Forecasting \& Social Change, 99, 267-272. https://doi.org/10.1016/j.techfore.2015.07.019.

Zang, D. (2014). The impact of two-sided messaging on brand attitude: An Attribution Theory approach (Master dissertation). Available from ProQuest Dissertations and Theses database. (UMI No. 1567252).

Zhang, X., Liu, S., Deng, Z., \& Chen, X. (2017). Knowledge sharing motivations in online health communities: A comparative study of health professionals and normal users. Computers in Human Behavior, 75, 797-810. https://doi.org/10.1016/j.chb.2017.06.028.

Zhao, L., Lu, Y., Wang, B., Chau, P.Y.K. \& Zhang, L. (2012). Cultivating the sense of belonging and motivating user participation in virtual communities: A social capital perspective. International Journal of Information Management, 32, 574-588. https://doi.org/10.1016/j.ijinfomgt.2012.02.006.

Zhou, T. (2011). Understanding online community user participation: A social influence perspective. Internet Research, 21(1), 67-81. https://doi.org/10.1108/10662241111104884.

Zietek, N. (2016). Influencer marketing: The characteristics and components of fashion influencer marketing (Master Dissertation). Borås: The Swedish School of Textiles. 
